UTILIZING CONSTITUTIONAL VALUES IN CONSTITUTIONAL

COMPARISON

ISSN 1727-3781

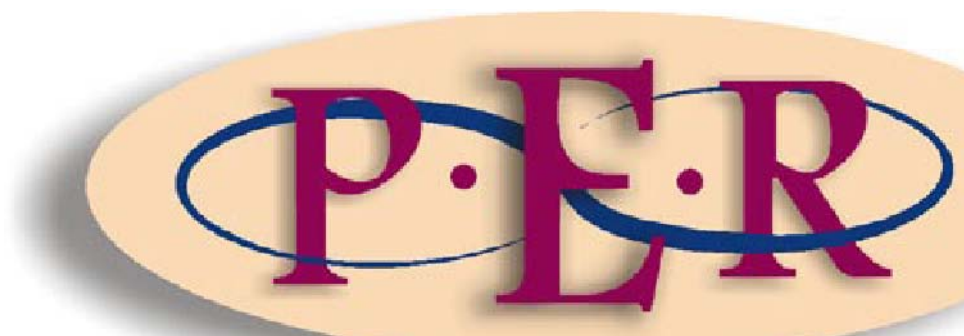

2001 VOLUME 4 No 1 


\title{
UTILIZING CONSTITUTIONAL VALUES IN CONSTITUTIONAL
}

\section{COMPARISON}

\section{Constitutional comparison}

\author{
Francois Venter
}

We are living in an era in which constitutional law has become a comparative science. This is not true only for developing constitutional states, but for the constitutional law of all constitutional states. The reason for this is that the history of modern constitutionalism has reached a global fullness of development, from which emanates a distinct set of commonalities, principles, standards and values that have gained currency in constitutional dialogue all over the world. Perhaps the best proof of this ripeness of constitutionalism is to be found in the signs that new, postmodern thinking about the state, the law and the sustainability of the established tenets of constitutionalism is pushing at the gates of globally received constitutional doctrine.

Despite this push for a postmodern replacement of modernist constitutional thinking, which is essentially the product of Euro-American thinking over many centuries, the contemporary constitutionalist inevitably continues to operate with this product. It entails constitutionally enshrined values, entrenched fundamental rights, judicial review, the separation of powers, democratic processes, etc. Exactly because these and similar constitutional notions share a multi-national history and universal acceptance as standards for sound constitutional structuring, the constitutional lawyer cannot but be a comparatist. The practice of constitutional comparison has become the norm in some, especially European, jurisdictions. There are however many jurisdictions where this is not the case and where the basic principles of the comparative practice are not well known. It is therefore worth the exercise to briefly introduce some of these principles before proceeding.

1 Cf Venter 257-262

2 The approach to constitutional comparison followed here, is more extensively dealt with in Venter F Constitutional Comparison (Juta and Kluwer Cape Town, Cambridge (MA) and Dordrecht 2000) Chapter 1. 
For the comparatist the first question must be what the material one wishes to compare, is to be compared with. This is often dealt with in terms of the notion of the tertium comparationis.

I would suggest that comparison, especially of legal institutions, rules, procedures and principles, will seldom produce valid knowledge if undertaken in abstracto. This does not mean that abstract comparison, be it by way of finding similarities or by listing contrasts and differences, is impossible. In fact, such a procedure will probably form part of every comparative exercise. It is however to be doubted that such an approach alone, unenriched by other methods, would produce results of much scientific value.

It is my contention that it becomes essential to identify the measure, standard, concept or basis against which legal comparison is to be undertaken as soon as one goes beyond a mechanical and superficial or abstract identification of similarities and differences. In order to be able to undertake a comprehensive comparison of complex material, it is necessary to delineate one's comparative framework, i.e. the tertium comparationis that is to be employed.

However, the nature of a specific comparative enterprise and of the material being compared must influence methodological decision-making. The comparability of material may be determined by the proximity of the legal problems, mechanisms and solutions in the compared systems, or by the complete diversity, the analysis of which could be considered to be useful precisely because of its "otherness".

Much in the process of legal comparison depends on the purpose for which it is undertaken. The purposes of one's comparative work can vary widely. There can be no doubt that the primary purpose of any exercise in legal comparison should be the creation of new knowledge or understanding of the law. This basic purpose is

3 Cf e.g. Burkens MC Methodologie van staatsrechtelijke rechtsvergelijking (Deventer 1975) 9: "Vergelijken is gericht op het zichtbaar maken van verschillen, door de te vergelijken objecten te betrekken op een gezichtspunt, waarin zij gelijkenis vertonen."

4 Zweigert K and Kötz H Einführung in die Rechtsvergleichung 3 ed (Tübingen 1996) 14 puts it succinctly: "Die primäre Funktion der Rechtsvergleichung ist - wie die aller wissenschaftlichen Methoden - Erkenntnis." 
however not sufficient to determine the appropriate method and approach to a specific comparative project. Many other more specific purposes might be pursued.

The more profound the purpose of comparison becomes, the more paradigmatic will the tertium comparationis be; the more emphasis is put on the production of new and verified scientific knowledge, the more important does the sensible comparability of the material become. But the degree and nature of comparability will most likely be co-determined by the nature of the chosen comparative standard or framework, i.e. the tertium comparationis.

There is no consistency of method to be observed in the practice of legal comparison - no less so in the field of constitutional law. Nor are there defensible grounds for the elevation of comparative law to the level of an autonomous legal discipline. One must simply accept that jurists have a need for comparative forays into foreign territory: some for very limited purposes of gathering information, and others for the generation of more fundamental knowledge. There can, it is therefore submitted, be no such thing as a universal, monolithic science or discipline of comparative law, be it in the field of private or of public law. On the other hand, juridical comparison done unscientifically will not yield the fruits of useful knowledge.

It is possible to distinguish various layers of legal comparison, some yielding superficial knowledge, and others varying degrees of richness of scientific insight. None of these is to be rejected, since it is unavoidable that the top layers must be penetrated and dealt with in order to reach the deeper, richer layers of comparative knowledge.

It is useful for constitutional comparison to distinguish between constitutional law and the law of the constitution. The former could indicate the broad discipline of law which concerns itself with the principles, mechanisms and rules applicable to the establishment, functioning and government of a state. Seen thus, the term "constitutional law" refers to all the relevant positive rules of law, but also to the concomitant doctrinal matters. The law of the constitution, on the other hand, could be used to indicate a subset of constitutional law, namely the actual provisions of a written constitution. 
For the constitutional comparatist, it is unavoidable to deal with the law of the constitution of the systems being studied. At first blush, this is not a difficult exercise, because it involves a simple juxtaposition of actual provisions dealing with similar subject-matter. However, constitutional texts require interpretation, and constitutional interpretation tends to be system-specific: the comparatist can easily misjudge the actual meaning of a foreign text if such a text is not interpreted in the relevant national hermeneutic context. It can thus be said that superficial textual comparison will very frequently represent the first layer of comparison, almost inevitably followed by a search for authoritative native interpretation. Such a search will in many cases lead one into a labyrinth of contextual, historical, judicial and academic analyses, penetrating to a deeper comparative layer. The comparatist's equipment to deal with these complexities will determine the degree of the effectiveness and depth of the comparison.

Constitutional law is very seldom revolutionary in the sense of completely replacing a previous system without leaving any traces of the replaced constitutional law. This is usually true also in cases of dramatic remodelling of systems or even where fundamental constitutional doctrines are replaced. It is also typical of renovated constitutional systems that they are influenced by foreign systems.

It is therefore not surprising that history plays such an important role in the study of any constitutional system. Nor is it strange to note that the study of the history of any element of the law of the constitution or of the constitutional law of a state enhances one's insight into the current state of the law. Moreover, conceptual commonalities between different systems can frequently be discovered and understood only against the background of history. Constitutional history therefore is a most valuable instrument for the comparatist working on a foreign system.

5 "Thus, e.g. Canadian constitutional law underwent fundamental change in 1982 through the introduction of the Canadian Charter of Rights and Freedoms and constitutional adjudication, but its original constitutional instrument of 1867 continues in operation." 
The deepest layer of understanding of a constitutional system takes the form of the philosophical precepts determining the principles and doctrines prevailing in that system. Because of the multi-faceted and abstract nature of the philosophical underpinnings of a constitutional system, they are often unknown or disregarded even by native lawyers. It is also very difficult, or even impossible, to achieve accuracy or conclusiveness in this regard, since philosophy, doctrine and principle can be highly subjective, speculative and contentious. Nevertheless, comparison of constitutional principles and doctrines holds the promise of a sound understanding of similarities and contrasts in the constitutional law of different states.

The purpose of an exercise in constitutional comparison is a very important consideration. Aimless comparison tends to result in meaningless and inconclusive juxtaposition. In order to produce valuable results, it should be clear what the stimulus for the comparative exercise is, what the nature of the framework within which the comparison will take place is, and also what the enterprise's purpose or goal is.

Comparability not only involves horizontal considerations of the nature of the subject-matter, but is also determined by the balancing of vertical penetration. This must be understood against the background of the foregoing exposition of the "layers of comparison": one cannot expect to achieve valuable results (or viable constitutional development) when, e.g. the naked constitutional text of one system is compared with the philosophical precepts of another. Were this not the case, there would have been no reason why new constitutions might not be written by means of a trans-national process of "cut-and-paste".That this has actually happened in various 
instances, is demonstrated by the failures and successes of the "reception" in places 6

of foreign constitutional systems.

\section{Values in constitutions}

The lawyer dealing with a constitutional document which serves as the foundational norm of the legal system concerned, is often confronted with broad formulations and imprecise notions. ${ }^{7}$ This may inspire unwarranted reactions, such as the rejection of the law of the constitution as "real" or "black letter" law, or it may seem like a justification of the idea that the constitution means what the judges wish it to mean. Such reactions are however not justifiable. Law, after all, is not merely composed of a closed set of clear-cut rules. Were that the case, lawyers and courts might have been replaced by computers. The law in general is in fact replete with unspecific notions such as justice, reasonableness, public interest, boni mores, and many others. It should therefore not be disturbing to find that values are often foundational to the operation and application of constitutional law.

However, what do we mean by "a constitutional value"? In the current context the term "value" certainly does not carry any connotation of material worth. As an abstract concept, it indicates a standard or a measure of good. A constitutional value may therefore be deemed to set requirements for the appropriate or desired interpretation, application and operationalization of the constitution and everything dependent thereupon. If something were not to conform to the standards of a particular value, it would mean that the standards of a lower, different, conflicting or extra-constitutional measure is being applied, which would therefore lead to

6 In this regard E McWhinney Supreme Courts and Judicial Law-making: Constitutional Tribunals and Constitutional Review (Dordrecht 1986) XIII revealingly states: "The phenomenon of 'reception' from one legal system to another, across differences of language and culture and legal-systematic organisation and experience, is not new of course; and sometimes, as with the Meiji 'reception' in Japan from 1867 onwards, it has been widespread and fundamental, where elsewhere, in comparison, it may have been a purely mechanical eclecticism that has never taken firm root and so has disappeared."

7 Concepts such as "democracy", "liberty", "popular sovereignty" abound in constitutions.

8 Some difficulties regarding the meaning of and distinction between terms such as principles, values and guidelines are to be found in Swanepoel J "Die dialektiek in die waardes van die 1996 Grondwet" 1998 Potchefstroomse Elektroniese Regstydskrif http://www.puk.ac.za/lawper/19981/jansw-die.html 
unconstitutional results. Constitutional values may therefore be said to be distinguishable but related to principles in the sense that the principles of the constitution would be founded in and give expression to the values. E.g. the principle that the law must be applied fairly and equitably, is founded in and gives expression to the values of justice and equality.

To employ constitutional values in the process of constitutional comparison therefore requires quite a penetrating consideration of the foundations of the systems being compared. Where the systems have, either in express constitutional terms or in terms of established doctrine, given expression to specific values, it is necessary for the comparatist to ascertain what the actual influence of those values are in the constitutional reality concerned. Where this is possible, a value chosen for comparison might be used profitably as a tertium comparationis.

Sundry examples of the expression of values in constitutions and international instruments help to demonstrate what we are dealing with. An extensive set of examples cannot be reproduced here. The following more or less random collection is drawn from a huge reservoir of examples from these and other constitutions:

The preamble of the Constitution of the United States of 1789 reads as follows:

We the People of the United States, in Order to form a more perfect Union, establish Justice, insure domestic Tranquillity, provide for the common defence, promote the general Welfare, and secure the Blessings of Liberty to ourselves and our Posterity, do ordain and establish this Constitution for the United States of America.

Popular sovereignty, justice, peace, public welfare and liberty may be considered to be some of the founding constitutional values of the United States expressed in the Preamble. The preamble is however not the only source of values, as will appear from the discussion below.

The preamble of the Hungarian Constitution of 1949 (as amended) reads: In order to facilitate a peaceful political transition to a constitutional state, establish a multi-party 
system, parliamentary democracy and a social market economy ...

Thus the constitutional state (Rechtsstaat), multi-party democracy and an economic system described as "a social market economy" were laid down as constitutional principles.

Article 1 of the Constitution of Greece of 1975 provides:

- Greece is a Parliamentary Democracy with a President as Head of State.

- $\quad$ Popular sovereignty is the foundation on which the form of government rests.

Here parliamentary democracy and popular sovereignty are entrenched as constitutional principles.

The preamble of the Moroccan Constitution of 1996 reads:

An Islamic and fully sovereign state whose official language is Arabic, the Kingdom of Morocco constitutes a part of the Great Arab Maghreb. As an African state, it has, among its objectives, the realisation of African unity. Aware of the need of incorporating its work within the frame of the international organisations of which it has become an active and dynamic member, the Kingdom of Morocco fully adheres to the principles, rights and obligations arising from the charters of such organisations, as it reaffirms its determination to abide by the universally recognised human rights. Likewise, it reaffirms its determination to continue its steady endeavours towards the safeguard of peace and security in the world.

Article 1 provides:

Morocco shall have a democratic, social and constitutional Monarchy. 
and article 2:

Sovereignty shall be that of the People who shall exercise it directly, by means of referendum, or indirectly, through the constitutional institutions.

The constitutional values enunciated here are Arabic Islamism, the promotion of African unity, the promotion of human rights and world peace and security, social democracy and popular sovereignty.

The preamble of the Constitution of Paraguay of 1992 reads:

Through their legitimate representatives convening at the National Constituent Assembly; pleading to God; recognizing human dignity for the purpose of ensuring freedom, equality and justice; reaffirming the principles of a representative, participatory, pluralistic republican democracy . . .

'Thus it may be said that the Paraguayan constitutional values are human dignity, freedom, equality, justice and "representative, participatory, pluralistic republican democracy".

In the cases of the German Grundgesetz and the Constitution of the Republic of South Africa 1996, substantive foundational provisions elevate specified values to a level of key importance.

Article 1(1) and (2) of the Grundgesetz of 1949 provide:

(1) The dignity of man is inviolable. To respect and protect it shall be the duty of all public authority.

(2) The German people therefore uphold human rights as inviolable and inalienable and as the basis of every community, of peace and justice in the world. 
Here we find human dignity as indisputable key value, supported by human rights, peace and justice.

The South African case is probably one of the most comprehensive contemporary examples. Section 1 of the South African Constitution provides as follows:

The Republic of South Africa is one, sovereign, democratic state founded on the following values:

(a) Human dignity, the achievement of equality and the advancement of human rights and freedoms.

(b) Non-racialism and non-sexism.

(c) Supremacy of the constitution and the rule of law.

(d) Universal adult suffrage, a national common voters roll, regular elections and a multi-party system of democratic government, to ensure accountability, responsiveness and openness.

To distil from these casually selected constitutions, and from many others that may be referred to, a set of universally acknowledged constitutional values, might be an interesting empirical exercise, but one that will not necessarily glean substantive truths. An identification of values that may be said to underpin modern constitutionalism may perhaps better be undertaken by means of a study of the history and underlying philosophy of constitutional theory. To do so here, is not the intention, but from only these few examples, it appears that constitutional values that tend to crop up frequently are human dignity, human rights, popular sovereignty, democracy, justice and equality.

\section{Comparing with values}

In the process of the identification of a value or set of values to be used as a comparative reference, the comparatist can expect to discover whether the systems that are being considered for comparison, are indeed good candidates for comparison. Comparability would not necessarily depend on whether the systems involved share the values exactly - comparison may also involve contrasting disparate systems. It may also be that systems share a particular value, but that it is 
interpreted and applied differently because of different histories and conditions in which they apply.

To briefly demonstrate, albeit superficially, the proposed method of constitutional comparison, let us select equality as value and tertium comparationis. Let us then consider, with reference to equality as value, the manner in which the perennially controversial mechanism of affirmative action is currently dealt with in the USA, Canada and South Africa. This choice of jurisdictions is based on the known role that considerations of equality promotion have played and continue to play in the three chosen societies, as well as the expectation that persuasive and exemplary or dissuasive influence has flowed from the oldest to the youngest of them.

As a first step it is necessary to identify the nature of our tertium comparationis. However it may present itself in constitutions, complete equality cannot be considered to be an achievable state of affairs in this life, but it does constitute an important goal in the perpetual quest for justice and equity. Complete arithmetical equality among humans does not exist and therefore a "right to equality" is, realistically speaking, not enforceable. As little as the law can achieve the perpetuation of life beyond the natural lifespan of the bearer of the right to life, can unqualified equality be brought into being by the juridical guarantee of equality. These are considerations that render equality to be a value, and not merely the object of a right.

The next step in our brief comparative undertaking must be the identification of the purpose of the comparison. From a South African point of view it can firstly be expected to be useful to trace the evolution of the constitutional notion of equality in systems that have influenced the local system; it would for this purpose be instructive to determine how our law relating to affirmative action coincides or differs from that of other systems; lastly, the comparative mirroring of the relevant law should provide one with insight into the essence of our own law relating to affirmative action.

Let us then plunge into a small comparative exercise. 
Mainly through the application of the Fourteenth Amendment to the United States Constitution, equality has achieved major importance in American jurisprudence. Given the heavy emphasis on procedural matters that typify the constitutional law of the USA, $^{11}$ it may not be self-evident that equality actually operates as a constitutional value in that system. Laurence $\mathrm{H}$ Tribe however removes any doubts on this account in Chapter 16 of his book. The following statement encapsulates it:

Indeed, the notion that equal justice under law may serve as indirect guardian of virtually all constitutional values is evidenced by more than a maxim carved in marble on the United States Supreme Court. That notion, expressed with growing frequency and even stridency throughout this century, wars with the idea that equality is liberty's great enemy and can be purchased only at an unacceptable price to freedom.

Affirmative action which is intended to benefit a race group, by definition relies on classification. In the famous Bakke case ${ }^{13}$ two divergent approaches to the matter of identifying a race group for affirmative preference were demonstrated in a divided court: in the one approach, strict racial classification for the purpose of preferring disadvantaged students access to medical school above students from the advantaged sections of society, was rejected, whereas the other approach considered it justifiable for the law not to be "colour-blind" under circumstances of historical racial disadvantagement. This "colour-blind "metaphor originated in a decision of the US Supreme Court of 1896 . $^{14}$ The judicial attitude towards affirmative action in the United States has since then however changed substantially, although opinions continue to be split in the judgments. In 1989 the US Supreme Court rejected the

9 The part most relevant for present purposes, is to be found in the last sentence of section 2 of the Amendment. It provides that no State shall "deny to any person within its jurisdiction the equal protection of the laws." The Fifth, Thirteenth and Fifteenth Amendments have however also been employed for the purpose by the courts: Tribe LH American Constitutional Law 2 ed (The Foundation Press Mineola 1988) 1437.

10 Consider e.g. Nowak JE, Rotunda RD and Young JN Constitutional Law 2 nd ed (West Publishing Co. St. Paul 1983) 585: "In recent years the equal protection guarantee has become the single most important concept in the Constitution for the protection of individual rights." Cf also Davis's discussion of American precedent in this regard in Van Wyk $\mathrm{D}$ (et al) Rights and Constitutionalism, The New South African Legal Order (Juta Cape Town 1994) 198-200.

11 Cf Erasmus in Van Wyk et al 633. 12 Tribe 1436. 13 Regents of the University of California $v$ Bakke 438 U.S. 265 (1978). 
constitutionality of a scheme to reserve the award of thirty percent of public construction contracts to racial minority owned companies. In 1995 the majority of the Supreme Court confirmed that, after almost a century, it now once more favoured an approach of "colour-blind" interpretation of the Constitution, allowing for affirmative action only where it is sharply focused to achieve a compelling governmental interest. In 1996 the State Constitution of California was amended following the popular approval of "Proposition 209", prohibiting discrimination against or the granting of preferential treatment to any individual or group on the basis of race, sex, colour, ethnicity or national origin in the operation of public employment, public education or public contracting, thus severely limiting the lawful pursuance of affirmative action programmes. The validity of this amendment was maintained by the courts. ${ }^{17}$ These tendencies show that the American perspective on the nature of equality as it features in the Fourteenth Amendment has over time shifted towards a marked resistance to exceptions to the rule against discrimination even for affirmative action purposes. ${ }^{18}$ The American experience also shows that the notion of affirmative action severely challenges the realization of the ideal of equal treatment.

The role of constitutional values in Canadian law is also quite prominent, despite the absence of any constitutional mention of values. With reference to the limitation of rights in terms of section 1 of the Charter, this role was described very clearly in the Oakes judgment:

The Court must be guided by the values and principles essential to a free and democratic society which I believe embody, to name but a few, respect for the inherent dignity of the human person, commitment to social justice and equality, accommodation of a wide variety of beliefs, respect for cultural and group identity, and faith in social and political institutions which enhance the participation of individuals and groups in society. The underlying values and principles of a free and

14 Plessey v Ferguson 163 U.S. 537 (1896) - cf Tribe 1521.

15 City of Richmond v JA Croson Co 488 U.S. 469 (1989).

16 Adarand Constructors, Inc. v Pena 515 U.S. 200 (1995)

17 Shirley LW "Reassessing the Right of Equal Access to the Political Process: The Hunter Doctrine, Affirmative Action, and Proposition 209" 1999 Tulane Law Review 1415 at 1425-8. 
democratic society are the genesis of the rights and freedoms guaranteed by the Charter and the ultimate standard against which a limit on a right or freedom must be shown, despite its effect, to be reasonable and demonstrably justified.

A further indication that equality may be considered to be a value underpinning the Canadian Constitution, appears from the introductory words of section 15(1). ${ }^{20}$ There the equality before and under the law is stated as a matter of fact, not of law, i.e. equality is projected as a pre-constitutional given, giving rise to the constitutional creation of the right to equal protection and equal benefit of the law.

However that may be, in the recent Granovsky judgment the Supreme Court distinguished "three broad inquiries" ${ }^{23}$ required by section 15(1). The idea of a three-stage enquiry under section 15 has however been settled in Canadian law for more than a decade.

In terms of section 1 of the Canadian Charter the rights that are protected in subsection (1) may be subjected to "such reasonable limits prescribed by law as can

18 A slightly cynical comment may however be that majority opinion or interests tend to be more influential in giving content to constitutional values than other factors.

19 R. v Oakes [1986] 1 S.C.R. 103, paragraph 64.

20 "Every individual is equal before and under the law and has the right to the equal protection and equal benefit of the law without discrimination and, in particular, without discrimination based on race, national or ethnic origin, color, religion, sex, age or mental or physical disability."

21 Curiously Hogg PW Constitutional Law of Canada 4 th ed (looseleaf) (Carswell 1997-1999)52-12 - 52-13 construes section 15(1) to provide for "four inequalities", the first two being equality before the law and equality under the law.

22 Granovsky v Minister of Employment and Immigration [2000] 1 S.C.R. 703

23 (1) Whether there is a differential treatment for the purpose of section15(1);

(2) whether this treatment was based on one or more of the enumerated and analogous grounds; and,

(3) whether the differential treatment brings into play the purpose of section15(1).

24 The cases of Andrews $v$ Law Society of British Columbia [1989] 1 S.C.R. 143 and $R v$ Turpin [1989] 1 S.C.R. 1296 have provided the foundation. In chapter 14 of Beaudoin G-A and Mendes E The Canadian Charter of Rights and Freedoms 3 ed (Carswell Scarborough 1996) 14-17, William Black and Lynn Smith described it in the following terms:

(1) Is there a denial of equality before or under the law, or of the equal protection or equal benefit of the law, to an individual?

(2) If there is a denial of equality, is it with discrimination, as defined by the Supreme Court in Andrews? There are two aspects to the determination of discrimination:

(a) the identification of the ground upon which the claim is based, to exclude cases not based upon enumerated or analogous grounds;

(b) meeting the definition of "discrimination"... 
be demonstrably justified in a free and democratic society." The scope for such limitation is naturally relatively limited, especially if a need is perceived for the advancement of particular persons or components of society.

The Bakke judgment of the US Supreme Court influenced Canadian thinking at the time of the drafting of the Canadian Charter of Rights and Freedoms. The need for government sponsored affirmative action programmes was considered to be desirable, and the drafters wished to avoid the difficulties that such a programme encountered in the United States. ${ }^{25}$ That would appear to have been the reasoning behind the wording of section 15(2) of the Canadian Charter.

Doctrinally Canadian affirmative action programmes that are expressly permitted by section 15(2), are deemed by some to constitute an exception to the prohibition of discrimination contained in subsection (1), inevitably involving "some element of reverse discrimination."27 Others however argue that subsection (2) "serves as an interpretative aid to subsection (1) and helps explain the concept of equality on which the entire section is based."28 The Charter itself does not extend to private action, and therefore does not protect an affirmative action programme which is not run by the state.29 However, provincial human rights codes, which in most cases also provide

(3) If there is a denial of equality with discrimination, is the provision or practice nevertheless a reasonable limit demonstrably justified in a free and democratic society, under section 1 of the Charter?

Weber A "Minderheitenschutz und Nichtdiskriminierung in Kanada in rechtsvergleichender Perspektive" 1994 EuGRZ 537 at 546-7. Black and Smith however seems to doubt this: cf Beaudion and Mendes 14-29 n122.

26 Subsection (1) does not preclude any law, program or activity that has as its object the amelioration of conditions of disadvantaged individuals or groups including those that are disadvantaged because of race, national or ethnic origin, colour, religion, sex, age or mental or physical disability.

27 Hogg 53-46

28 Beaudoin and Mendes 14-27 et seq

29 Hogg 52-11-52-12 and section 32 of the Charter. 
for affirmative action programmes, have on rare occasions had the unexpected effect of indirectly justifying private affirmative action. 30

In the South African Constitution the notion of equality appears in the heavily entrenched founding provision (section 1), in various provisions of the Bill of Rights and in sections 185 and 187 with reference to two constitutional commissions.31

In the Bill of Rights,32 section 9 addresses equality most specifically in subsections (1) and (2). Subsections (3)-(5) deal with the opposite of equal treatment, namely discrimination. Subsection (3) prohibits unfair discrimination by the state, subsection (4) prohibits private discrimination and subsection (5) creates the assumption that discrimination on specified grounds is unfair. Express provision is made in subsection (4) for legislation to be adopted to prohibit private discrimination.33

Without the employment of the specific term, "affirmative action" is allowed in subsection (2), supported by the second sentence of subsection (4), section 217(2) of the Constitution allowing for a procurement policy favouring the disadvantaged and section $146(2)(c)(v)$ which is aimed at ensuring that national legislation which

30 Such human rights codes are ordinary statutes, and are therefore subject to the Charter. Should provision be made in a human rights code for exceptions to equal treatment additional to the exceptions of section 15(2) of the Charter, such additions are exposed to the danger of being struck down. This occurred e.g in the Blainey case in 1986 (Hogg 52-11 - 52-12) where a girl complained of being discriminated against on the grounds of her sex by being excluded from a boy's hockey team. The Ontario Human Rights Code prohibited sexual discrimination, but excepted single-sex sports teams as justifiable. This exception was found to be inconsistent with the provisions of section 15 of the Charter, thus leaving only the prohibition of sexual discrimination, and thus opening the boy's team to membership for the girl!

31 The Commission for the Promotion and Protection of the Rights of Cultural, Religious and Linguistic Communities and the Commission for Gender Equality.

32 9. (1) Everyone is equal before the law and has the right to equal protection and benefit of the law.

(2) Equality includes the full and equal enjoyment of all rights and freedoms. To promote the achievement of equality, legislative and other measures designed to protect or advance persons, or categories of persons, disadvantaged by unfair discrimination may be taken.

(3) The state may not unfairly discriminate directly or indirectly against anyone on one or more grounds, including race, gender, sex, pregnancy, marital status, ethnic or social origin, colour, sexual orientation, age, disability, religion, conscience, belief, culture, language and birth.

(4) No person may unfairly discriminate directly or indirectly against anyone on one or more grounds in terms of subsection (3). National legislation must be enacted to prevent or prohibit unfair discrimination.(5) Discrimination on one or more of the grounds listed in subsection (3) is unfair unless it is established that the discrimination is fair.

33 The Promotion of Equality and Prevention of Unfair Discrimination Act 4 of 2000 has been adopted for this purpose. 
promotes equal opportunity and access to government services will prevail over concurrent provincial legislation.

In the Constitution equality as a constitutional value is presented in two forms: firstly as an idealistic aim ("the achievement of equality") and secondly as a descriptive element of the kind of treatment that one should receive ("equal protection and benefit of the law" and "equal enjoyment of all rights and freedoms").

A substantial volume of South African constitutional jurisprudence on equality has accumulated over the past few years.

The Constitutional Court has developed a compact methodology for the structured application of the anti-discrimination clause. It amounts to three main stages in the form of answers to the following questions:

(a) Does the conduct differentiate between people or categories of people?

(b) If so, does such differentiation amount to unfair discrimination?

(c) If unfair discrimination is established, can the conduct be justified under the limitation provision (section 36)?

The similarity of this test to the Canadian test described above, is so obvious that it 39

can not be co-incidental.

34 Section 1 and the second sentence of section 9(2)

35 Section $9(1)$

36 Section 9(2)

37 Brink v Kitshoff 19964 SA 197 (CC), Prinsloo v Van der Linde 19973 SA 1012 (CC), President of the Republic of South Africa and Another v Hugo 19974 SA 1 (CC), Harksen $v$ Lane 19981 SA 300 (CC), Larbi-Odam and Others v MEC for Education (North West Province) 19981 SA 745 (CC) en Pretoria City Council v Walker 19982 SA 363 (CC). These judgments on the 1993 Constitution have been found to be equally applicable to the 1996 Constitution: cf par [15] of the judgment per Ackermann $\mathrm{j}$ in National Coalition for Gay and Lesbian Equality $v$ Minister of Justice 19991 SA 6 (CC).

38 Para [53] of the Harksen judgment, paras [17] and [18] of the Gay and Lesbian judgment In para [24] of Hoffmann v South African Airways CCT 17/00 (decided on 28 September 2000), Ngcobo J compactly formulated the first enquiry more comprehensively: does "the provision under attack make a differentiation that bears a rational connection to a legitimate government purpose"?

39 It is however mildly puzzling that the South African Court has, as far as I could ascertain, not expressly given the Canadian Court the credit due to it. 
Affirmative action measures are allowed by the second sentence of section 9(2) "to promote the achievement of equality" while the first sentence defines "the full and equal enjoyment of all rights and freedoms" as a constituent element of the state of equality. This wording reduces the contrast between the proscription of discrimination and the admission of preferential treatment of the disadvantaged. The wording chosen for section 9(2) therefore tends to counter the interpretation favoured by some in Canada that affirmative action represents an exception to the right to equal treatment. I would however suggest that the provision would still not allow unfair discrimination in the name of affirmative action. The appropriate mechanism for the determination of the border line between lawful promotional programmes and unconstitutional discrimination, probably lies in the nature of the programmes and the meaning that should be given to the term "disadvantaged.

The notion of disadvantage is key to the justification in all three systems of government action that benefits some above others, despite the constitutional injunctions to equal treatment. In a footnote in the judgment of the US Supreme Court of 1938 in the Caroline Products case, the term "discrete and insular minorities" was coined. The Supreme Court took the position that such minorities required special protection by the judiciary because the ordinary democratic processes could not afford them appropriate protection.

The phrase was adopted in 1989 by the Canadian Supreme Court in the Andrews case when it suggested that section 15 of the Canadian Charter required disadvantage on the part of groups protected by the provision. ${ }^{44}$ Since then, however, it would appear that it has been settled in Canadian law that "while historical disadvantage or a group's position as a discrete and insular minority may serve as indicators" that discrimination took place on a ground analogous to those expressly mentioned in section 15, they are not prerequisites for finding such grounds. It however speaks for itself that affirmative action measures are pertinently directed at was made in Public Servants Association of South Africa v Minister of Justice 19973 SA 925 (T). United States v Caroline Products Co. (1938) 304 U.S. 144

42 Hogg 52-37 - 52-38.

43 Andrews $v$ Law Society of B.C. [1989] 1 S.C.R. 143

44 Hogg 52-36.3 
disadvantaged persons or groups, since section 15(2) expressly utilizes the term. In the Canadian Charter the notion of "disadvantaged" is left open and unqualified ("disadvantaged individuals and groups").

In section 9(2) of the South African Constitution, however, the condition that qualifies persons and categories of persons to benefit from protective or advancing measures, is "disadvantaged by unfair discrimination". In the historical context of the country, this certainly cannot be understood to refer only to "discrete and insular minorities", but the wording of section 9(2), which allows for affirmative action, would certainly have to be interpreted with reference to the meaning of "unfair discrimination". Persons who are to benefit from special programmes must therefore be characterized by the fact that they have been "disadvantaged by unfair discrimination."

For comprehensive results, the foregoing comparative foray into the three systems needs to be extended substantially, but even this very brief exercise has produced some useful insights:

- in the USA equality increasingly underpins a strict proscription of discrimination, thus shrinking the scope for justifiable affirmative action programmes;

- the South African law relating to discrimination and upliftment of the disadvantaged was clearly influenced by, and is therefore better understood against the background of, the equivalent arrangements in Canada, which was in its turn possibly conceived against the backdrop of early developments in this regard in the USA;

- the Canadian doctrine and law of the constitution deals with affirmative action as an exception to the prohibition of discrimination and does not favour private affirmative action programmes;

- the South African approach seeks on the one hand to promote equality as a near-absolute prohibition of discrimination, while on the other hand affirmative action is projected not as an exception to non-discrimination, but as a means of achieving equality;

45 Egan v Canada [1995] 2 S.C.R. 513, 599, described and quoted by Hogg 52-40 - 52-41. 
- whereas the identification of disadvantage in the USA and Canada tends to focus on discrete and insular minorities, the South African Constitution deals with an obvious reality of past disadvantage of a substantial majority, thus probably giving preferential programmes in South Africa a different character.

In broad terms it emerges from our short survey that equality is indeed a key foundational value in all three the jurisdictions, but that important differences in emphasis exist, limiting comparability. To illustrate: it would not be convincing to quote the latest American decisions in South Africa to make a case for a "colourblind" approach to affirmative action. Nor would one be justified to argue, with reference to one Canadian school of thought, that affirmative action should be dealt with as an exception to the proscription of discrimination while there is also a persuasive argument in Canadian literature that the affirmative action provision gives content to the basic concept of equality. In fact, the latter approach appears to fit in very well with the wording of the South African Bill of Rights.

\section{Conclusion}

The question that may arise, is whether the methodological proposals advanced in this paper, would really make any difference to the validity, usefulness or comprehensiveness of the results that may be gleaned from constitutional comparison. Put bluntly, is it really necessary go about systematically, identifying and describing a tertium comparationis when doing comparative work?

One possible answer to this may be that lawyers have not been doing too badly by going about their comparisons in an instinctive and unstructured manner. This is naturally true for some of the work that has been published, but certainly not of all.

In South African writings and jurisprudence a huge amount of comparison has been going on since 1994. One does however get the impression that too much eclecticism has accompanied comparisons in some instances, while in others, much benefit could have been gleaned from comparison, if it were done. 
In the inaugural decision of the South African Constitutional Court, the landmark death penalty case, a great deal of comparative information is reflected in the main judgment. This was however done against the background of a slightly laconic consideration of the need for comparison, leading to the conclusion that there was no strong obligation on the Court to do so. Nevertheless, reference, in some cases extensively, was made to material from the United States, Canada, Germany, India, Hungary, Tanzania, Zimbabwe, European human rights documents and jurisprudence and various instruments of international law. Exactly how all this comparative material impacted on the eventual finding of the Court (the correctness of which is not here in dispute) is not particularly clear.

In contrast to the wealth of comparative information in the Makwanyane judgment, the opportunity, or, it is submitted, need, for comparative analysis, was wholly absent from the Constitutional Court's decision in the Lesapo case, where much reliance was placed on the notion of the rule of law. The Court did refer to some previous dicta of its own in which the uncertain content of the doctrine and its relationship to the German notion of the Rechtsstaat were intimated, but refrained from contributing anything to an authoritative interpretation of the phrase "rule of law" in section 1(c) of the Constitution, other than quoting Dicey.

It is naturally impractical when doing comparisons always to provide an explication of one's methodology. It is however submitted that the absence of an appropriate comparative method, be it expressed or not, puts the tenability and usefulness of the comparative exercise at risk. Employing fundamental notions such as constitutional

46 Cf e.g. Van Reenen TP "Equality, discrimination and affirmative action: an analysis of section 9 of the Constitution of the Republic of South Africa" 1997 SAPR/PL 151 at 162.

47 S v Makwanyane 19953 SA 391 (CC).

48 In para [34] Chaskalson $P$ wrote: "The international and foreign authorities are of value because they analyse arguments for an against the death sentence and show how courts of other jurisdictions have dealt with this vexed issue. For that reason alone they require our attention." This is followed in para [37] with the following statement: "Comparative 'bill of rights' jurisprudence will not doubt be of importance, particularly in the early stages of the transition when there is no developed indigenous jurisprudence in this branch of the law on which to draw." The Court however concludes at the end of that paragraph that the Constitution did not contain an injunction to the courts to do more than to "have regard to" foreign case law.

49 Chief Lesapo v North West Agricultural Bank 20001 SA 409 (CC)

50 E.g. in paras [16] and [18] 
values as a tertium comparationis, holds the promise of profoundly meaningful results. In this regard, South African jurisprudence is clearly in need of extensive methodological development.

Comparing with values has, at the very least, the potential of revealing to us which foreign sources can justifiably be used locally as authoritative or persuasive references, and which not.

51 Para [16]. 